$\begin{array}{cl}\text { Türkiye Tarımsal Araştırmalar Dergisi } & \text { Turk J Agric Res } \\ \text { http://dergi.siirt.edu.tr } & \text { (2016) 3:37-40 } \\ \text { (1) TÜTAD }\end{array}$

\title{
The Effects of Light and Temperature on Germination of Stevia (Stevia rebaudiana BERT.) Seeds
}

\author{
Esra UÇAR ${ }^{*}$, Yaşar ÖZYIĞİT ${ }^{2}$, Kenan TURGUT $^{3}$ \\ ${ }^{l}$ Cumhuriyet University, Sivas Vocational School, Organic Agriculture Programme, Sivas, TURKEY \\ ${ }^{2}$ Akdeniz University, Korkuteli Vocational School, Horticulture Programme, Antalya, TURKEY \\ ${ }^{3}$ Akdeniz University, Agricultural Faculty, Field Crops Department, Antalya, TURKEY
}

Received: 26.10 .2015

Accepted: 28.01 .2016

${ }^{*}$ Corresponding author: eucar@cumhuriyet.edu.tr

\begin{abstract}
The Stevia rebaudiana (Bert.) Bertoni is a perennial herbaceous plant and belongs to family of Asteraceae (Compositae). The contents of $S$. rebaudiana (Bert.) Bertoni consist mainly non-caloric stevioside and rebaudioside A sweeteners. Low seed germination is an important problem in stevia cultivation. Therefore in this study, the effects of light and temperature on germination performance of stevia seeds were studied. Stevia rebaudiana seeds were treated with two lights (light/darkness) and four different temperatures $\left(15^{\circ} \mathrm{C}, 20^{\circ} \mathrm{C}, 25{ }^{\circ} \mathrm{C}, 30^{\circ} \mathrm{C}\right)$. For each treatment, 50 seeds were counted and placed into petri dishes. Experiments were conducted as a randomized complete design method with three replicates. Germination was started within 6 to 10 days depending on the treatments. The highest seed germination rate (71\%) was observed in darkness $/ 25{ }^{\circ} \mathrm{C}$ temperature and followed by darkness $/ 20{ }^{\circ} \mathrm{C}(68 \%)$ and light $/ 25{ }^{\circ} \mathrm{C}(67 \%)$. On the other hand, the lowest seed germination rate $(31 \%)$ was obtained from $15^{\circ} \mathrm{C}$ in both light and dark conditions and followed by darkness $/ 30{ }^{\circ} \mathrm{C}(43 \%)$ and light $/ 30{ }^{\circ} \mathrm{C}(49 \%)$. The results showed that lower $\left(15{ }^{\circ} \mathrm{C}\right)$ and higher $\left(30{ }^{\circ} \mathrm{C}\right)$ temperatures significantly decreased the germination rates of stevia independently from the light treatments.
\end{abstract}

Keywords: Stevia rebaudiana, seed, germination, temperature, light

\section{Introduction}

The Stevia rebaudiana (Bert.) Bertoni is a perennial plant, called also sweet herb, in the family of Asteraceae (Compositae). It is a shortday plant (Handro and Ferreira, 1989) and florets of this plant are tiny white. At the same time, the average weight of 1000 seeds is $300 \mathrm{mg}$. It's seeds consist of slender achenes, about $3 \mathrm{~mm}$ in length (Goettemoeller and Ching, 1999). The yield of seed production associated with last stem cutting time, planting density and number of bloom (Macchia et al., 2007). The sweet herb is originated in South America (Paraguay and Brazil) (Andolfi et al., 2006; Harrington et al., 2011). Extracts of sweet herb are being consumed as natural sweetener in a number of countries, particularly in Japan, China, Korea and Brazil and the leaves of sweet herb have non-caloric diterpenes and glycosides such as stevioside and rebaudioside-A. These glycosides in leaf of sweet herb are 300-350 times sweeter than sucrose without any side effects. This natural property is very important for diabetics, dieters and people who care about their health. On the other hand, sweet herb has some significant medicinal effects such as hypoglycemic, oral contraceptive, cardiovascular and antimicrobial activity (Das et al., 2008; Kumar and Sharma, 2012). The sweet herb is self-incompatible and insect pollinated and clear seeds are infertile (Goettemoeller and Ching, 1999). From the literature, it appears that five pollination treatments and germination of seeds have been studied, and these are cross-pollination by bumble bees $(78.3 \%)$; cross-pollination by hand (92.0\%); cross-pollination by wind $(68.3 \%)$; selfpollination by hand $(93.3 \%)$ and control $(36.3 \%)$. It was showed that seed germination increases with all pollination treatments. Generally, the seed germination of sweet herb is poor, therefore the large-scale cultivation of this plant is limited (Goettemoeller and Ching, 1999; Kumar and 
Sharma, 2012). Since the seed germination is not adequate, propagation through seeds is too few (Taware et al., 2010). Generally propagation is through stem cuttings (Abdullateef and Osman, 2011). Genetic determinants and environmental factors are related to germination (Başbağ et al., 2009). Light is one of the important factors, in order that the photosynthesis, which is significant for organic products and cellular activities of plants and plant development, becomes. At the same time, light plays important role for seed germination and seedling growth of some plants. Presence of light can influence some seeds to germinate but in some seeds can bring inhibition (Abdullateef and Osman, 2011).

One of the deterministic factors of development of a plant is temperature since all metabolic processes are affected by it. Therefore optimum temperature is considerably important for germination rate of stevia seeds. It may decrease at higher or lower temperatures than optimum temperature (Roberts, 1988). Furthermore, the amount of calender time to develop a certain developmental stage shows differences due to the effect of temperature (Olivier and Annandale, 1998).

Sweet herb has low seed germination and this is a significant problem in stevia cultivation. Therefore, this study was carried out to determine germination performance of stevia seeds at different temperature and light conditions.

\section{Materials and Methods}

\subsection{Seed collection}

Mature seeds were collected from second year stevia plants grown in the field conditions in October 2012 and then stored in room temperature until germination tests. Flowers of those plants were pollinated by honey bees.

\subsection{Germination experiments for temperature and light}

Germination experiments were conducted in a programmed incubator with cool white fluorescent lamps (6.000 lux) in the Department of Field Crops, Faculty of Agriculture, Akdeniz University, in 2012. The experiment was conducted as a randomized complete design method with three replicates. In the experiment, there were eight treatments with two light conditions (light and dark) and four different temperatures $\left(15^{\circ} \mathrm{C}, 20\right.$ $\left.{ }^{\circ} \mathrm{C}, 25{ }^{\circ} \mathrm{C}, 30{ }^{\circ} \mathrm{C}\right)$. Each treatment consisted of three plates and each plate was contained 50 seeds.50 seeds were placed into each petri dish (90 $\mathrm{mm}$ ) which contained blotting paper wetted with distilled water. After that, petri dishes were closed and wrapped with paraffin and placed in the incubator with the four different temperature 15 ${ }^{\circ} \mathrm{C}, 20{ }^{\circ} \mathrm{C}, 25{ }^{\circ} \mathrm{C}, 30{ }^{\circ} \mathrm{C}$ and two different light (light and darkness) application for two weeks (Table 1). In darkness treatment, petri dishes were covered completely with aluminium foil so that no light could enter. First germination day was determined as seeds were considered germinated when the rootlet reached the length of the seed itself (Macchia et al., 2007). The number of germinated seeds was counted every day and final counting was recorded after two weeks.

Germination percentage (GP \%) was calculated with following formula:

$$
\mathrm{GP}=\mathrm{NGS} / \mathrm{NTS} \times 100
$$

NGS $=$ Number of germinated seeds, NTS $=$ Number of total seeds

Table 1. Treatments used in the germination test

\begin{tabular}{cc}
\hline Treatments & Temperature / Light Conditions \\
\hline T1 & $15^{\circ} \mathrm{C} /$ light \\
T2 & $15^{\circ} \mathrm{C} /$ dark \\
T3 & $20^{\circ} \mathrm{C} /$ light \\
T4 & $20^{\circ} \mathrm{C} /$ dark \\
T5 & $25^{\circ} \mathrm{C} /$ light \\
T6 & $25^{\circ} \mathrm{C} /$ dark \\
T7 & $30^{\circ} \mathrm{C} /$ light \\
T8 & $30^{\circ} \mathrm{C} /$ dark \\
\hline
\end{tabular}

\subsection{Statistical analysis}

Experimental data were analysed by SAS. Randomized complete block design was employed for comparing of temperatures, light conditions and their reciprocal interactions in the seed germination percentage. The means of the examined traits were ordered according to Duncan's multiple range tests.

\section{Results and Discussion}

Results of the experiments are presented in Table 2. According to the results, first germination days were affected significantly by light/darkness and temperature treatments $(\mathrm{P}<0.01)$. The difference between means of light and darkness treatments was found to be important, and mean of first germination in light condition (6.8 days) was earlier than in dark condition (7.3 days) (Table 2).

The lowest temperature $\left(15^{\circ} \mathrm{C}\right)$ gave the latest germination time in both light ( 9 days) and dark (10 days) conditions, and was appeared to be significantly different from other temperatures (6 and 7 days). On the other hand, $20^{\circ} \mathrm{C}, 25^{\circ} \mathrm{C}$ and $30{ }^{\circ} \mathrm{C}$ treatments were placed into same statistical group.

According to the results, germination percentage was significantly affected by the 
Table 2. First Germination Time and Germination Percentage of Stevia rebaudiana (Bert.) Bertoni seeds with different temperature and different light

\begin{tabular}{ccccccc}
\hline & \multicolumn{2}{c}{ First germination time $(\text { Days })^{* *}$} & \multicolumn{2}{c}{ Germination percentage $(\%)$} \\
\hline Temperature $\left({ }^{\circ} \mathrm{C}\right)$ & Light & Dark & Means & Light & Dark & Means \\
\hline 15 & $9 \mathrm{~A}$ & $10 \mathrm{~A}$ & $10 \mathrm{~A}$ & $31 \mathrm{C}$ & $31 \mathrm{~B}$ & $31 \mathrm{C}$ \\
20 & $6 \mathrm{~B}$ & $7 \mathrm{~B}$ & $7 \mathrm{~B}$ & $59 \mathrm{AB}$ & $68 \mathrm{~A}$ & $64 \mathrm{~A}$ \\
25 & $6 \mathrm{~B}$ & $7 \mathrm{~B}$ & $6 \mathrm{~B}$ & $67 \mathrm{~A}$ & $71 \mathrm{~A}$ & $69 \mathrm{~A}$ \\
30 & $6 \mathrm{~B}$ & $6 \mathrm{~B}$ & $6 \mathrm{~B}$ & $49 \mathrm{~B}$ & $43 \mathrm{~B}$ & $46 \mathrm{~B}$ \\
\hline LSD & 1.3314 & 1.0871 & 0.6688 & 14.257 & 13.446 & 9.1496 \\
\hline Means & $6.8 \mathrm{~B}$ & $7.3 \mathrm{~A}$ & $51.5 \mathrm{~A}$ & $53.1 \mathrm{~A}$ &
\end{tabular}

Mean differences with different letters within the same column are statistically significant $\left(^{* *}: \mathrm{P}<0.01\right)$

temperature $(\mathrm{P}<0.01)$. In light condition, the highest germination percentage was recorded at 25 ${ }^{\circ} \mathrm{C}(67 \%)$ and followed by $20{ }^{\circ} \mathrm{C}(59 \%)$ and $30{ }^{\circ} \mathrm{C}$ (49\%). The lowest germination percentage was obtained from $15{ }^{\circ} \mathrm{C}(31 \%)$ and it was statistically important. In darkness, there were two statistical groups; the highest germination percentages were determined at $25{ }^{\circ} \mathrm{C}(71 \%)$ and $20{ }^{\circ} \mathrm{C}(68 \%)$ and the lowest ones were obtained from $30{ }^{\circ} \mathrm{C}(43 \%)$ and $15{ }^{\circ} \mathrm{C}(31 \%)$ (Table 2).

In both light and darkness, $15{ }^{\circ} \mathrm{C}$ treatment gave the lowest germination percentage and followed by $30{ }^{\circ} \mathrm{C}$ treatment. In this experiment, $25^{\circ} \mathrm{C}$ was appeared to be optimum temperature for higher germination rate either in light or in darkness. Also, $20{ }^{\circ} \mathrm{C}$ could be suitable for higher germination rate particularly in darkness (Table 2).

In the means of light and darkness, $25^{\circ} \mathrm{C}$ and $20{ }^{\circ} \mathrm{C}$ were statistically in the same group and significantly higher than others, and $15{ }^{\circ} \mathrm{C}$ was the lowest rate (Table 2).

Temperature is one the most important environmental factor determining the success of germination and all seeds need proper temperature for germination. Generally, low temperatures significantly delayed the germination (Pourreza and Bahrani, 2012). Kumar and Sharma (2012) reported that stevia seed germination is hampered by low temperature.

Also sometimes germination can be negatively affected by higher temperatures (Pourreza and Bahrani, 2012). Sharma (1976) determined that while high temperatures $\left(>30^{\circ} \mathrm{C}\right)$ are unfavourable for germination and cause injury to seeds and seedlings, lower temperatures $\left(<15^{\circ} \mathrm{C}\right)$ are also inhibitory but do not cause permanent damage to seeds. The same researcher reported that a large percentage of seedlings died soon after germination and turned black at temperatures higher than $30{ }^{\circ} \mathrm{C}$, while at $40{ }^{\circ} \mathrm{C}$ seeds were damaged permanently. This case explains why germination percentage was reduced at $30{ }^{\circ} \mathrm{C}$ in our study. Kawatani et al. (1976) reported that optimum temperature for seed germination of stevia was $20^{\circ} \mathrm{C}$. In another study, Takahashi et al. (1996) compared germination performance of stevia under different temperatures $\left(20,25,30^{\circ} \mathrm{C}\right)$ and reported that maximum germination occurred at $25^{\circ} \mathrm{C}$ with $90.3 \%$.

In conclusion, germination percentage of stevia was significantly affected by the temperature but light did not reveal any difference. The highest seed germination rates were observed in $25^{\circ} \mathrm{C}$ and $20{ }^{\circ} \mathrm{C}$ temperatures. On the other hand, the lowest seed germination rates were obtained from $15^{\circ} \mathrm{C}$ and $30^{\circ} \mathrm{C}$.

\section{References}

Abdullateef, R.A., Osman, M., 2011. Effects of visible light wavelengths on seed germinability in Stevia rebaudiana Bertoni. International Journal of Biology, 3(4): 83-91.

Andolfi, L., Macchia, M., Ceccarini, L., 2006. Agronomic-productive characteristics of two genotype of Stevia rebaudiana in Central Italy. Italian Journal of Agronomy, 1(2): 257-263.

Başbağ, M., Toncer, O., Başbağ, S., 2009. Effects of different temperatures and duration on germination of caper (Capparis ovata) seeds. Journal of Environmental Biology, 30(4): 621-624.

Das, K., Dang, R., Shivananda, T.N., 2008. Influence of bio-fertilizers on the availability of nutrients $(\mathrm{N}, \mathrm{P}$ and K) in soil in relation to growth and yield of Stevia rebaudiana grown in South India. International Journal of Applied Research in Natural Products, 1(1): 20-24.

Goettemoeller, J., Ching, A., 1999. Seed germination in Stevia rebaudiana. In: J. Janick (Ed), Perspectives on New Crops and New Uses, ASHS Press, Alexandria, VA., pp. 510-511.

Handro, W., Ferreira, C.M., 1989. Stevia rebaudiana (Bert.) Bertoni: Production of natural sweeteners. Biotechnology in Agriculture and Forestry, 7: 468487.

Harrington, K.C., Southward, R.C., Kitchen, K.L., He, X.Z., 2011. Investigation of herbicides tolerated by Stevia rebaudiana crops. New Zealand Journal of Crop and Horticultural Science, 39(1): 21-33.

Kawatani, T., Kaneki, Y., Tanabe, T., 1976. The cultivation of kaa he-e (Stevia rebaudiana). II Seed 
germination with particular reference to the optimum temperature and light sensitivity. Japanese Journal of Tropical Agriculture, 20(3): 137-142.

Kumar, R., Sharma, S., 2012. Effect of light and temperature on seed germination of important medicinal and aromatic plants in north western Himalayas. International Journal of Medicinal and Aromatic Plants, 2(3): 468-475.

Macchia, M., Andolfi, L., Ceccarini, L., Angelini, L.G., 2007. Effects of temperature, light and pre-chilling on seed germination of Stevia rebaudiana (Bertoni) Bertoni Accessions. Italian Journal of Agronomy, 2(1): 55-62.

Olivier, F.C., Annandale, J.G., 1998. Thermal time requirements for the development of green pea (Pisum sativum L.). Field Crops Research, 56(3): 301-307.

Pourreza, J., Bahrani, A., 2012. Estimating cardinal temperatures of milk thistle (Sylibum marianum) seed germination. American-Eurasian Journal of
Agricultural \& Environmental Sciences, 12(11): 1485-1489.

Roberts, E.H., 1988. Temperature and seed germination. In: S.P. Long, F.I. Woodward (Eds), Plants and temperature, Symposia of the Society of Experimental Biology, Cambridge, 42: 109-132.

Sharma, M.L., 1976. Interaction of water potential and temperature effects on germination of three semiarid plant species. Agronomy Journal, 68(2): 390394.

Takahashi, L., Melges, E., Carneiro, J.W.P., 1996. Germination performance of seeds of Stevia rebaudiana (Bert.) Bertoni under different temperatures. Revista Brasileira de Sementes, 18(1): 6-9.

Taware, A.S., Harke, S.N., Mukadam, D.S., Chavan, A.M., Taware, S.D., 2010. Effect of different extracts of callus and plantlets of Stevia rebaudiana (Bertoni) on seed germination of some agricultural crops. African Journal of Biotechnology, 9(40): 6675-6683. 